\title{
INVESTIGATION OF PHYSICAL ENVIRONMENT AS A PART OF MICRO DIMENSION IN RESTAURANTS: A STUDY ON LOCAL CONSUMERS
}

\section{GAS}

Yayın Bilgileri

Geliş Tarihi: 27.07 .2020

Kabul tarihi: 14.09.2020

Yayın tarihi: 30.10.2019

Yazar Bilgileri

ORCID:

* 0000-0003-1549-0834

**0000-0002-4561-1310

Email:

* nserceoglu@atauni.edu.tr

**mehmetyavuzcetinkaya@hotmail.com
* Neslihan ÇETINNKAYA

** Mehmet Yavuz ÇETINKAYA

\section{ABSTRACT}

In today's world, restaurants are not the places where people only supply their eating and drinking needs by necessity, they act as business enterprises as well, which enable people to interact one another in terms of socio-cultural aspect. However, consumers' demands have important impacts on turning restaurants into these roles. Even, the increase in the number of alternative restaurants has made customers try new restaurants. For this reason, restaurants do need to satisfy customers' consumption-related feelings alongside their eating experience to make their present customers loyal and attract new customers as well. In other words, the factors such as aesthetics, ambiance and physical factors/drivers including seating place preference, table and plate evaluation of the restaurants that consumers prefer/will prefer is a must that needs to be used as a criterion of success by the restaurants. In this vein, this study aims to investigate the physical environment in the restaurants as a part of micro dimension. A questionnaire form was developed through scales, related to the subject, and field research was carried out. The study findings unveiled that there are positive significant relationships among the variables such as; participants' educational qualification and seating place preference, participants' income level and plate evaluation, participants' seating place preference and restaurant's aesthetics and lastly, participants' seating place preference and table evaluation. The study also unveiled that the physical environment generally does constitute important criteria on consumers' preference in the restaurants.

Keywords: Key Words: Restaurants, Physical Environment, Local Consumers, Erzurum. 


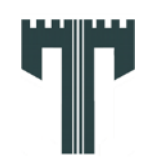

Gastroia: Journal of Gastronomy and Travel Research, Vol. 4, Issue 2, pp.,218-250 , 2020

Investigation of Physical Environment as a Part of Micro Dimension in Restaurants: A Study on Local Consumers

Neslihan ÇETINKAYA, Mehmet Yavuz ÇETINKAYA

\section{INTRODUCTION}

The culture of eating and drinking, which dates back to ancient times is, a phenomenon developed and commercialized in due course. The commercialization of eating and drinking necessity that people need to survive in life has begun with the emergence of restaurants. Restaurants were opened primarily to meet the needs of wealthy families and men eating out (Tannahill, 1988). However, restaurants were defined as workplace or service location where foods and beverages are prepared and served to customers in return for a certain amount of money in the following years (Zencir, 2017:3). Once the development of the restaurants is examined historically, it is obvious to see that changes in consumer demands seem to be a major factor in this development. The fact that alternative restaurants and rivals increased in numbers have brought along the necessity of providing the needs of consumers. In general, consumers would like to be in a good atmosphere, feel comfortable, spend an enjoyable time and become satisfied while meeting their eating need. For this reason, restaurants known as food and beverage enterprises operating in tourism industry need to create differences that can appeal to every type of consumer groups to satisfy existing customers more and increase the number of customers. In general, there are several factors and drivers playing an important role when to make a restaurant more preferable in comparison with its rivals in the market. These factors are generally; to have a good and qualified service, to have qualified service staff, to make salesperson work effectively, to follow consumers' wishes and needs and lastly, changes in the market. On the other hand, the restaurants, which have a bad service, not qualified service staff, lack of consumer and market research, not developing new products and services, not caring consumers' demands, ignoring them, and not following the changes in the market (Türksoy, 1997:28) generally do not provide the sustainability in the food and beverage market with a high level of competition.

Kivela, Inbakaran and Reece (2000) state that consumers prefer to re-eat in the restaurants when they are satisfied with the criteria they take into consideration. For this reason, restaurants need to realize the activities to increase their brand value in terms of factors that affect restaurant preference (K1lınç and Çavuş, 2010). This situation also supports the creation of competitive advantage in business enterprises. There are some academic studies tackling and shedding light into what can be done to create competitive advantage in business enterprises (Vaheeduzzan and Ryans 1995; Mintzberg et al., 1998; Ma, 1999). The enterprises that operate in food and beverage sector which analyze the customers in the target market better than their rivals, offer product and services intended for the customers by being aware of their needs and wishes and evaluate the opportunities correctly are more likely become a threat for their rivals (Güler, 2007:102). In this case, the restaurant's design, atmosphere, and physical factors, which have been dwelled on in recent years, have importance as important as service quality.

There are findings obtained from various previously conducted researches that uncover those physical factors/environmental conditions affect customer satisfaction, which is among the customers' perceived quality criteria (Wakefield and Blodgett, 1996; Wirtz and Bateson, 1999; Ryu and Han, 2010). Therefore, restaurants need to make their customers have an unforgettable experience for eating in order to increase customer satisfaction. In 


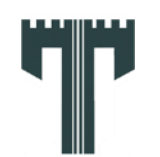

Gastroia: Journal of Gastronomy and Travel Research, Vol. 4, Issue 2, pp.,218-250 , 2020

Investigation of Physical Environment as a Part of Micro Dimension in Restaurants: A Study on Local Consumers

Neslihan ÇETINKAYA, Mehmet Yavuz ÇETINKAYA

order to achieve this, firstly, the physical areas where the service is offered must be shaped in accordance with the customer demands. When the studies, which dwell into the relation of the physical environment with eating experience, are examined, it is obvious to see that the researches generally come to an agreement that physical environment influences customers in one way or another. From this point of view, this study aims to investigate the physical environment of restaurants in terms of micro dimension and determine the impacts of the physical environment on consumers. Accordingly, the author carried out field research via the scales developed on aesthetics, ambiance, seating place preference, table, and plate evaluation and to what extent consumers are influenced from the physical environment on restaurant preference has been revealed as well.

\section{LITERATURE REVIEW}

\section{Importance of Food and Beverage Sector}

The importance of the food and beverage sector is increasing with each passing day and developing rapidly in the global competitive atmosphere. This sector, which is one of the growing sectors in Turkey, does have the most basic reasons for its development. These basic reasons are; the increase in income level and in the number of working women and intense work pressure of individuals and their tendency to eat out (Ariker, 2012:11;Bekar and Dönmez, 2016:2). The growth of the food and beverage sector, which is based on food and beverage service in accordance with the statistics of Turkish Restaurant \& Entertainment Association (TURYID) is 6.5 billion $\$$ in Turkey. The situation when looked like the physical and recreational need in the context of travel, it is clear to see that touristic consumers who have experience far away from their usual home approach or perceive both as a physical satisfaction purposefully and enjoyable tasting activity that contributes traveling experience.

During a touristic journey, providing the need for eating and drinking contributes directly to tourism income of the visited country. Upon examining the tourism income of Turkey for the last two years, it might be seen that 4.822 billion $\$$ of tourism income standing for 26.283 billion $\$$ in 2017 was spent for the need of eating and drinking which is one of the personal expenditure items. In 2018, this rate was 6.966 billion $\$$ of tourism income accounting for 29.512 billion $\$$ have occupied a significant place in the budget as a food and beverage expenditure (Turkish Statistical Institute, 2019).

The food and beverage sector also meets the non-physical needs of people. The quality of service is quite important in enterprises operating in food and beverage sector when considered that the needs and wishes of people are met with the benefits produced by others and these benefits are explained with the service concept. In this sector, which is a labor-intensive one, the products have heterogeneity and this causes the differentiation in service quality. Because each service presentation and the feeling that this presentation leaves on customers is different. Even, when the producers, presenters, and consumers of the service are the same people and all the process of service are developed like in previously obtained benefits, two presented services are perceived differently because of the time difference and due to this reason, it becomes difficult to standardize the service. 


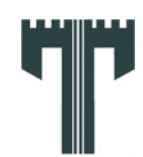

Gastroia: Journal of Gastronomy and Travel Research, Vol. 4, Issue 2, pp.,218-250 , 2020

Investigation of Physical Environment as a Part of Micro Dimension in Restaurants: A Study on Local Consumers

Neslihan ÇETINKAYA, Mehmet Yavuz ÇETINKAYA

In the literature review, when the reasons which improved food and beverage sector are examined, it is clear to see that both the role of people' necessity and reasons that lead people to food and beverage business enterprises namely the reasons for eating outside. The need for eating and drinking which is the most basic need of human beings is assessed in the first category entitled as physical needs of Maslow's Hierarchy of Needs. According to Maslow, when the needs that are the most basic and intensive are not met, uneasiness arises in the selfless of people. In this vein, it is quite normal that people suffering from hunger and thirst will probably look for a place where they can meet their eating and drinking needs. It might be said that all people may become potential customers for the food and beverage enterprises as they all become hungry and thirsty. However, the aim of food and beverage enterprises should not be only to relieve people' feeling of hunger and thirst at this point. They should also mediate the socialization of people as a social being. For this reason, restaurants via considering competitive atmosphere today do not only aim to eat one's fill, but they also target to make innovations constantly with the qualified service concept. As a result, the development of the sector continues.

\section{The Concept of Eating Out}

In today's world, people can provide their eating and drinking needs with their own means in their homes as well as going out to eat considering a set of conveniences under today's circumstances. According to Özdemir (2010), today's societies consume products increasingly, which are produced in the food and beverage sector. This consumption is regarded as a result of people' behavior of eating out. The phenomenon of eating out which became one of the most important parts of everyday life accounts for the consumption of food and beverage which are produced out of people' present homes (Cullen, 1994; Kant and Graubard, 2004; Jaafar et al., 2009). Warde and Martens (2000) state that eating out is a way of marketing social differences. In the commercial sense, it stands for the consumption of food and beverage produced and served in a food and beverage enterprise outside of people' homes in return for a certain fee (Özdemir, 2010:218). In addition, Narine and Badrie (2007) also consider eating out as a production and consumption phenomenon. The common ground in all ideas is that people decide to meet their eating and drinking needs outside of their homes in order to experience eating out (Gregory and Kim, 2004:83).

There are many reasons that direct people to go out for eating in food and beverage business enterprises. According to Maslow's Hierarchy of Needs, people prefer to eat out due to different reasons in order to meet their eating and drinking needs in line with the research findings. These reasons mainly are; being convenient, time saving, economic situation, participation in cultural activities, search for different tastes, status indicator, etc. (Türksoy, 1997; Gregory and Kim, 2004; Park, 2004;Narine and Badrie, 2007; Özdemir, 2010; Kılınç and Çavuş, 2010).

On the other hand, Cullen (1994) conceptually classified the potential reasons showing why people go out for eating and created a distinction between social eating and convenience eating. Therefore, social eating is explained as socialization during the meal, being happy, having fun, getting better spiritually whereas convenience eating stands for the food not prepared at home in simple terms, preferring the simple one and being 


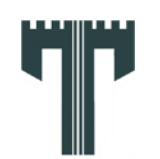

Gastroia: Journal of Gastronomy and Travel Research, Vol. 4, Issue 2, pp.,218-250 , 2020

Investigation of Physical Environment as a Part of Micro Dimension in Restaurants: A Study on Local Consumers

Neslihan ÇETINKAYA, Mehmet Yavuz ÇETINKAYA

economic. In addition, Park (2004) evaluated the reasons why consumers eat out in different ways. He stated that when people prefer to eat out because it is simple and economical, beneficial value comes into prominence whereas when they eat out due to reasons such as pleasure, delight, and happiness, then hedonic values rise to prominence. Lastly, Özdemir (2010) categorized the reasons for people eating out in four main groups. These groups; physical, psychological, economic and social dimensions. Physical dimension explains the eating and drinking needs of people compulsorily. Psychological dimension is expressed as a preference to eat out in order to have pleasure and happiness. Economic dimension accounts for the preference of people who want to eat without losing any time. Moreover, people who do not cook/cannot cook at home prefer to eat out. Finally, the social dimension stands for the socialization of people during a meal, having status and prestige. In this vein, Özdemir (2010) stated that Cullen's (1994) convenience eating concept type is explained with the physical and economic dimensions. In addition, Park's (2004) beneficial value concept is explained with the physical and economic dimensions and hedonistic value concept is expressed with physiological and social dimensions.

The common subjects of the academic studies previously carried out on the issue of eating out in international academic literature have been determined such as restaurant, meal selection criteria, context, sociology and economic dimensions of eating out and lastly, satisfaction and loyalty level of customers' eating out. On the other hand, the issue of eating out has been investigated in such a way that; it has been framed with the meals eaten out of the home and correlated to the home economy in Turkish literature. In addition, the majority of academic studies focused on why people consume fast food predominantly rather than focalizing why people eat out. As a result, reasons such as service speed, saturation, and easy access have led people for such an eating preference.

In academic literature, there are researches/studies shedding light into the way showing how people make the decision for eating out. This situation, which is assessed as consumer behavior, is correlated with the preference, purchase, and usage of the products and experiences in order to meet the needs of people (Gregory and Kim, 2004:83). The subject of consumer behavior which is one of the sub-divisions of human behavior involves the process of people' decision making; which products and services, how, where and when are purchased. This process, which is expressed as the process of consumer decision making, is two-phased (Johnson and Payne,1985). In the first phase, the present alternatives are examined in line with the selection criteria and in the second phase, narrowed alternatives are examined in detail and compared with the other alternatives (Haubl and Trifts, 2000). The selection criteria varying from one person to another person and type of products is assessed with the different criteria when to choose a restaurant which is one of the people' foods and beverage enterprise. Consumers consider many factors while choosing the restaurant they go for eating out (Harrington et al., 2011). There are a number of researches previously conducted on the criteria, which became effective for choosing the restaurant (Lewis, 1981; Auty, 1992;Clark and Wood, 1998; Kivela et al., 1999a; Kivela et al., 1999b; Kivela et al., 2000; Barta, 2008; Njite et al., 2008; Raab et al., 2009; Özdemir, 2010; Harrington et al., 2011; Ariker, 2012; Albayrak, 2014; Yüksekbilgili, 2014; Bekar and Dönmez, 2016). 
Investigation of Physical Environment as a Part of Micro Dimension in Restaurants: A Study on Local Consumers

Neslihan ÇETINKAYA, Mehmet Yavuz ÇETINKAYA

Lewis (1981) carried out research and divided the criteria for selecting a restaurant into five aspects. These criteria; food quality, menu diversity, price, atmosphere, and convenience. Further, Auty (1992) identified the most important criteria for choosing restaurants, which are menu diversity, food quality, price, atmosphere, and location. Clark and Wood (1998) found out that food diversity, food quality, price, atmosphere and service speed are the most important criteria in choosing the restaurant. Albayrak (2014) made a literature review of the factors that influence consumers' restaurant preference and created a detailed table. Accordingly, related criteria; atmosphere, menu/food diversity, quality and healthiness of food, price, region, quality and cleanness of the products and services, behavior of employees, speed of service, food ingredients, comfort, child option, working hours and image of the restaurant and return for the paid money.

Özdemir (2010) uncovered the criteria compromising of three main factors in his research as a literature review, which he was inspired by Shepherd (2001). These criteria were determined through correlating the person choosing the meal, meal itself and environment. For this reason, the criteria for choosing where to eat is divided into three parts such as person-related factors, meal-related factors, and environmental-related factors. The personrelated factors while choosing the meal are listed as; health, mood/physiology, sensory perception (taste, smell,etc.) weight control/physical image perception, ethical concerns, cultural ethnic, philosophical and environmental concerns, taste, nutrition concerns, personality, experience, and gender. The factors related to meal preference are listed as; price, naturalness, health and nutritional benefits/nutritional value, food safety/sanitation, brand, taste, smell, tissue, awareness, conformity, and satiety. Lastly, the factors related to the environment are listed as; culture, food trends, marketing, time, economic and social factors.

In general terms, there are six different criteria which are effective while choosing a restaurant or making a preference on a restaurant in the academic studies shedding light into criteria on restaurant selection. These criteria are; the quality of food, menu/food diversity, the price of the meal/food, restaurant's atmosphere, and image, location, and convenience of the restaurant, type of service for meal and food. Taking into related criteria, generally, there is a concept emerging as a physical environment or described as a service environment. This environment is the place where the sale of products and services is realized and the atmosphere in which it is located. The place was the environment where producers and consumers are to sell and to purchase at the same time; the atmosphere is a concept showing how this environment is perceived by the customers.

\section{Relation between Physical Environment and Eating Behavior}

In the academic studies, which investigated the relationship between the physical environment and eating behavior and the impact of the physical environment on eating behavior, a number of models and theories were included. The most commonly used/applied models are Gestalt Approach and Mehrabian-Russell Model. In Gestalt Approach, the customers entering to restaurant perceive the physical environment through deduction and in the following phases, the perception continues from general to the specific. In other words, customers who come to restaurant perceive restaurant as a whole instead of perceiving the restaurant in line with the characteristics including table, chair, 


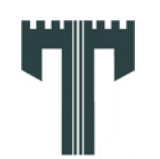

Gastroia: Journal of Gastronomy and Travel Research, Vol. 4, Issue 2, pp.,218-250 , 2020

Investigation of Physical Environment as a Part of Micro Dimension in Restaurants: A Study on Local Consumers

Neslihan ÇETINKAYA, Mehmet Yavuz ÇETINKAYA

and decoration, sound, light, smell, employee, etc. (Mil, 2012:18-19). According to this model, customers fully evaluate the restaurant. On the other hand, in Mehrabian-Russel Model which tries to explain the impacts of the physical environment on human behaviors, the physical environment in which service is presented influences perceptions related to service happening in the environment via affecting or influencing people' beliefs and judgments. In this model, the physical environment causes emotional reactions to people. These emotions cause people to develop attitudes such as approach or avoidance towards behaviors happening in the restaurant (Mil, 2012:24). Impression management stands for people' controlling their own behaviors in order to create the impact that will arise positive consequences for them (Devrani, 2014:143). In other words, all the attempts that people do to influence others with their behaviors, sayings, and appearances (Özdevecioglu and Erdem, 2008). For instance, the efforts of staff responsible for service and working in the restaurants in order to create a good impression on customers can be valued in the context of impression management. As a result of researches on this subject, it was found out that service staff could get more tips (Seiter, 2007; Seiter and Weger, 2010).

Baker (1987) carried out the first research investigating the relationship between the physical environment and eating behavior. In the research entitled as "The Role of the Environment in Marketing Services: The Consumer Perspective”, the dimensions of the physical environment were classified as the factors such as ambiance, design and social. Ambiance factor means the quality of air, noise, smell and cleaning factors. Design factor accounts for aesthetic and functional elements and lastly, social factor stands for the other customers and service staff. According to Baker (1987) concrete (aesthetic and functional) and non-physical (ambiance components) affect social interaction.

Mil (2012) conducted a research entitled as "Space Perception (Spaceception): Effects on Tourists' Dining Experiences and Satisfaction" and explained the relationship between the physical environment and eating experience. However, in order to make this explanation, the researcher stated that physical environment should be divided into dimensions within itself and in this context; the physical environment is divided into three dimensions such as micro, mezo and macro. The micro dimension involves the table, plate, and meal that customers prefer in the restaurant; mezo dimension includes the place where food buffet and food tables are located and lastly, macro dimension consists of the restaurant, general area covering the entire service area. Besides, the researcher explained the concepts of seating preference and area, eating environment, functional and hedonic value and satisfaction and aimed to measure tourist satisfaction through using a scale for each.

Gültekin, Akin and Özkoçak (2016) state that to design a restaurant is a difficult process. Because it is generally necessary that physical and physiological information techniques should be implemented and safety regulations related to work should be made in order to make rest areas and living quarters ergonomic. In the process of designing a restaurant, it is highly difficult to pay attention to these techniques and regulations. In addition, when the subject is examined anthropometrically namely, the human body's sizes are based on, designing becomes more difficult. It may be difficult to satisfy customers when the service staff and customers are considered to be in different sizes. Similar researches on this subject emphasize the seating preference of customers in restaurants. In other words, 


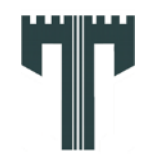

Gastroia: Journal of Gastronomy and Travel Research, Vol. 4, Issue 2, pp.,218-250 , 2020

Investigation of Physical Environment as a Part of Micro Dimension in Restaurants: A Study on Local Consumers

Neslihan ÇETINKAYA, Mehmet Yavuz ÇETINKAYA

customers care the importance of seating place preference in restaurants they prefer, they mostly prefer tables with a view or located next to the window and even they accept to pay more for the tables with a better location. Additionally, the customers assess tables, which are close to each other in distance, are not preferred and tables with $15 \mathrm{~cm}$ distance as uncomfortable. The fact that $70 \%$ of the customers who are placed at such tables demand to change their place, which was uncovered by some researches (Robson, Kimes, Becker and Evans, 2011).

When customers enter a restaurant for the first time, they first pay attention to aesthetic and ambiance of the restaurant choose a seating place and then evaluate the buffet and tables where foods are placed and in the final stage finish the sense of satisfaction by evaluating the food inside the plate. Restaurant aesthetic and ambiance are also considered as restaurant atmosphere in the related literature. Bitner (1992) examined the restaurant atmosphere in three dimensions (conditions, spatial layout, functionality, signs and symbols, works) and expressed these dimensions as service scape meaning service environment. Servicescape is the physical and social area in which the service is realized and customers realize all physical and non-physical perceptions related to consumers (Mil, 2012:43). According to human behaviors, which are strongly compatible with the physical area, people mostly, feel the atmosphere when they first step into a restaurant or before they purchase the service and see the foods (Ha and Jang, 2010: 520). In this case, it may be said that the restaurant atmosphere or aesthetic with ambiance has an impact on satisfaction level. In order to have satisfaction, customers need to be satisfied with their seating place as well as table and plate.

Once the customers have entered the restaurant, they look for the most appropriate place where they can be seated. This situation is sometimes determined consciously and sometimes results in the settlement of a random table. When the preference is made consciously, customers generally become satisfied whereas an unconscious preference is made for seating place without being aware in accordance with the physiological situation created by the environment. The seating preference is influenced by the restaurant's aesthetics and ambiance in both cases. In the short-term decision phase, some factors such as a comfortable table, its attractiveness, and decoration help customers to make a decision. In addition, characteristics of items and service tools on the table may also help customers in the decision-making process to eat in the restaurant. In this vein, the following hypotheses were formulated in line with the literature.

\section{$\mathbf{H}^{1}$ : There is a significant difference between participants' demographic characteristics and restaurant aesthetics.}

$\mathrm{H}^{1 \mathrm{a}}$ : There is a significant difference between participants' gender and restaurant aesthetics.

$\mathrm{H}^{1 \mathrm{~b}}$ : There is a significant difference between participants' age group and restaurant aesthetics.

$\mathrm{H}^{1 \mathrm{c}}$ : There is a significant difference between participants' educational qualification and restaurant aesthetics. 
Gastroia: Journal of Gastronomy and Travel Research, Vol. 4, Issue 2, pp.,218-250 , 2020

Investigation of Physical Environment as a Part of Micro Dimension in Restaurants: A Study on Local Consumers

Neslihan ÇETINKAYA, Mehmet Yavuz ÇETINKAYA

$\mathrm{H}^{1 \mathrm{~d}}$ : There is a significant difference between participants' income group and restaurant aesthetics.

$\mathbf{H}^{2}$ : There is a significant difference between participants' demographic characteristics and restaurant ambiance.

$\mathrm{H}^{2 \mathrm{a}}$ : There is a significant difference between participants' gender and restaurant ambiance.

$\mathrm{H}^{2 \mathrm{~b}}$ : There is a significant difference between participants' age group and restaurant ambiance.

$\mathrm{H}^{2 \mathrm{c}}$ : There is a significant difference between participants' educational qualification and restaurant ambiance.

$\mathrm{H}^{2 \mathrm{~d}}$ : There is a significant difference between participants' income group and restaurant ambiance.

$\mathbf{H}^{3}$ : There is a significant difference between participants' demographic characteristics and seating place preference.

$\mathrm{H}^{3 \mathrm{a}}$ : There is a significant difference between participants' gender and seating place preference.

$\mathrm{H}^{3 b}$ : There is a significant difference between participants' age group and seating place preference.

$\mathrm{H}^{3 c}$ : There is a significant difference between participants' educational qualification and seating place preference.

$\mathrm{H}^{3 \mathrm{~d}}$ : There is a significant difference between participants' income group and seating place preference.

$\mathbf{H}^{4}$ : There is a significant difference between participants' demographic characteristics and table evaluation.

$\mathrm{H}^{4 \mathrm{a}}$ : There is a significant difference between participants' gender and table evaluation.

$\mathrm{H}^{4 \mathrm{~b}}$ : There is a significant difference between participants' age group and table evaluation.

$\mathrm{H}^{4 \mathrm{c}}$ : There is a significant difference between participants' educational qualification and table evaluation.

$\mathrm{H}^{4 \mathrm{~d}}$ : There is a significant difference between participants' income group and table evaluation.

$\mathbf{H}^{5}$ : There is a significant difference between participants' demographic characteristics and plate evaluation. 
Gastroia: Journal of Gastronomy and Travel Research, Vol. 4, Issue 2, pp.,218-250 , 2020

Investigation of Physical Environment as a Part of Micro Dimension in Restaurants: A Study on Local Consumers

Neslihan ÇETINKAYA, Mehmet Yavuz ÇETINKAYA

$\mathrm{H}^{5 \mathrm{a}}$ : There is a significant difference between participants' gender and plate evaluation.

$\mathrm{H}^{5 \mathrm{~b}}$ : There is a significant difference between participants' age group and plate evaluation.

$\mathrm{H}^{5 \mathrm{c}}$ : There is a significant difference between participants' educational qualification and plate evaluation.

$\mathrm{H}^{5 \mathrm{~d}}$ : There is a significant difference between participants' income group and plate evaluation.

$\mathbf{H}^{6}$ : There is a significant difference between participants' seating place preference and restaurant aesthetics.

$\mathbf{H}^{7}$ : There is a significant difference between participants' seating place preference and restaurant ambiance.

$\mathbf{H}^{8}$ : There is a significant difference between participants' seating place preference and table evaluation.

$\mathbf{H}^{\mathbf{9}}$ : There is a significant difference between participants' seating place preference and plate evaluation.

The common purpose of any restaurant, which predicts high service quality, is to make people' common eating and drinking needs unforgettable. In recent years, there have happened some academic studies, which investigated the relations between the characteristics of the environments in which services are provided and consumer preferences. In this sense, this research tried to determine to what extent the physical environment affects customers in restaurants. Therefore, the research model, which is developed to evaluate the physical environment as a part of the micro dimension, is shown in Figure 1.

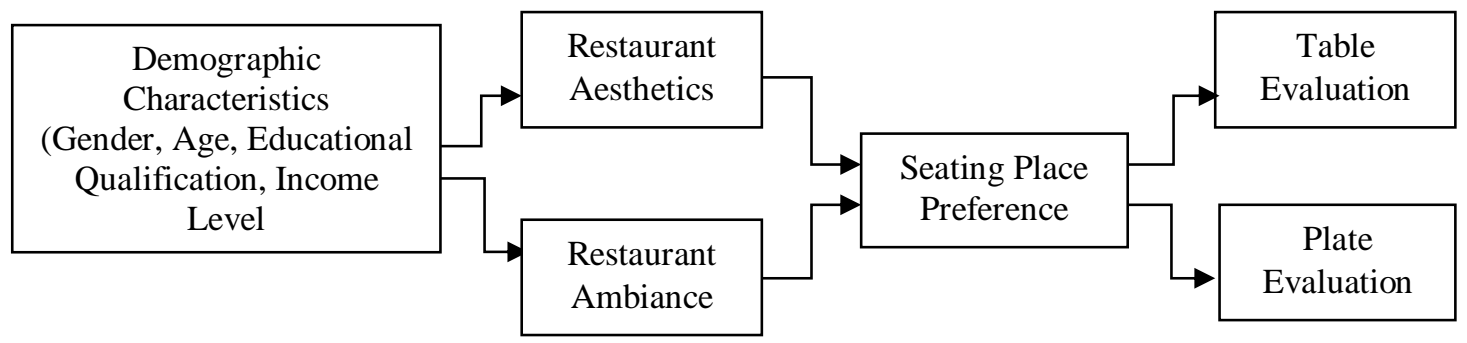

Figure 1. Research Model 


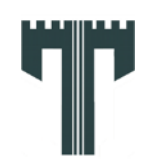

Gastroia: Journal of Gastronomy and Travel Research, Vol. 4, Issue 2, pp.,218-250 , 2020

\section{Investigation of Physical Environment as a Part of Micro Dimension in Restaurants: A Study on Local Consumers \\ Neslihan ÇETINKAYA, Mehmet Yavuz ÇETINKAYA}

\section{METHODOLOGY}

This study investigates; to what extent consumers who prefer to meet their eating and drinking experience out in a restaurant pay attention to characteristics such as aesthetics, ambiance, seating place preference, table, plate, etc., which are used as a marketing strategy. The scope of the study forms the physical environment, which has risen to prominence on the shaping process of consumers in recent years and highly affects consumers' preference. The author determined field research as a research strategy. In field research, which is expressed as descriptive research or survey as well, it is important to learn, what people think; their opinions and assessments on a subject. If the variables related to society and individuals involved in field research are comprised of demographic characteristics such as gender, marital status, educational qualification, age group, income level, profession, etc. these are called independent variables. People' thoughts, perceptions, etc. their psychological and sociological behaviors consist of dependent variables in researches. In this study, consumers' demographic characteristics are addressed as independent variables and perceptions on the physical environment in restaurants are dependent variables addressed in this study.

The research questions are as following;

* What is the impact of the physical environment on consumers in restaurants?

* Is there any relation between the physical environment and consumers 'eating in a physically better restaurant?

The author determined the questionnaire survey as a data collection method to answer the above-written questions and a questionnaire form was applied to consumers. The survey method eased the process to reach consumers and based the research to wider masses. In addition, when almost everybody eats out from time to time at certain periods is thought; to reach consumers and learn what they think through questionnaire form also eased the research process. The author made an intensive literature review during the preparation process of the questionnaire form, utilized five different scales, and prepared questionnaire questions. The scales used in the questionnaire form are shown in Table 1. 5-point Likert was applied in the evaluation process of the scales.

Table 1. The Scales applied in Questionnaire Form

\begin{tabular}{c|c}
\hline Scale & Item \\
\hline Aesthetics Scale & 4 Items \\
\hline Ambiance Scale & 5 Items \\
\hline Seating Place Scale & 4 Items \\
\hline Table Scale & 10 Items \\
\hline Plate Scale & 7 Items \\
\hline
\end{tabular}

Aesthetics Scale: Aesthetics means as a product's tastes, smells, touches, hears, and addresses the senses (Lindstrom, 2006:33). Aesthetics value is the dimension of consumption that appeals to emotions (Oral and Celik, 2013:4). All business enterprises whose interior design is effective on consumers' purchasing preferences to provide a competitive advantage in the sight of other business enterprises by adding aesthetic value 


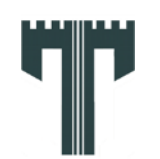

Gastroia: Journal of Gastronomy and Travel Research, Vol. 4, Issue 2, pp.,218-250 , 2020

Investigation of Physical Environment as a Part of Micro Dimension in Restaurants: A Study on Local Consumers

Neslihan ÇETINKAYA, Mehmet Yavuz ÇETINKAYA

to their service (Schmitt \& Simonson, 1997:13). Particularly, aesthetics accepted as a factor and influencing experimental value in food and beverage enterprises is observed to influence consumers' perceptions. Because restaurants aim to improve the reasons for consumers' preferences by offering aesthetics elements as well as providing customers' eating and drinking needs. In a restaurant in which is decorated by taking aesthetics factors or elements into consideration, customers approach other products of the enterprises with the same point of view as well as meals (Charters, 2006: 223-224) and they intend to make re-visit to the same restaurant.

Kim and Moon (2009) state that there are six characteristics of restaurants aesthetic. These characteristics are; external environment, exterior construction, interior construction, scoreboards, facility cleanliness, and staff appearance. The author used the aesthetic scale applied by Kim and Moon (2009). The items or expressions, which are involved in aesthetic scale including non-physical elements of the restaurant, are as follows.

* This restaurant's architecture gave it an attractive character.

* This restaurant was decorated in an attractive fashion.

* The use of color in the de'cor scheme adds excitement to the restaurant environment.

* The interior de'cor of this restaurant was attractive.

Ambiance Scale: The concept of ambiance stands for the beauty and comfort of the environment presented to consumers in restaurants. The ambiance, which is associated with music, light, and warmth in the environment, consists of non-physical factors of the restaurants. This study utilized the ambiance scale applied by Kim and Moon (2009). The expressions or items involved in the scale are as follows;

* The overall lighting level in this restaurant environment was appropriate.

* The temperature in this restaurant was comfortable.

* The aroma in this restaurant was pleasant.

* The background music played overhead made this restaurant a more enjoyable place.

* The restaurant environment was positive, and left me with very good feelings.

Seating Place Scale: The consumers who evaluate the atmosphere of the restaurant positively start the following process by choosing or preferring seating place namely, they choose the table that they prefer/will prefer and make an evaluation of table and plate. While consumers are choosing or preferring their seating place, they do not want any stranger sitting next to them and they demand to be seated comfortably (Yama et al., 2004). The seating place scale was developed through the scale used by Mil (2012) which he took these scale items and expressions from the scale, which was developed by Wulf (1977) and later adapted to restaurant environment by Hwang and Yoon (2009). Besides, some expressions from Pedersen's (1979) seating preference were added to the scale as well. The expressions or items involved in the scale are as follows;

* I care a lot about location of my table in a restaurant.

* I do not mind sitting at a table around with high traffic around and less privacy.

* I prefer highly private tables located against a wall or a window. 


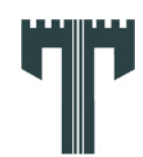

Gastroia: Journal of Gastronomy and Travel Research, Vol. 4, Issue 2, pp.,218-250 , 2020

\section{Investigation of Physical Environment as a Part of Micro Dimension in Restaurants: A Study on Local Consumers \\ Neslihan ÇETINKAYA, Mehmet Yavuz ÇETINKAYA \\ * I am willing to pay more for a better located table.}

Table Scale: Table layouts in the restaurants are quite effective on consumers' preference for the restaurant. When the design of the restaurants is made, tables, which are placed at very close distances, come to prominence as a negative feature on consumers' experiences. According to Robson et al., (2011) tables, which are placed at the $15 \mathrm{~cm}$ distance of each other, are thought to be uncomfortable and crowded. $70 \%$ of the consumers stated that they would like to change their table when they were placed at a table with a $15 \mathrm{~cm}$ distance level. In addition, it was found out that consumers who were placed at tables, which were very close to each other, intend to eat quickly, spend less time and money. It is thought that the scale used for tables' evaluations, which are considered as the superficial environment in which foods are served and consumed (Gold, 2002) to help to perceive the personal environment, which is subject to eating behavior (Becker and Mayo, 1971). The scale for the table was developed through the scale applied in the research carried out by Mil, (2012). The expressions or items involved in the scale are as follows;

* The table was comfortable

* Table lining (table cloth, napkins, etc.) was of high quality.

* Table arrangements were conducive to a pleasant conversation with others.

* The table was appearing neat, precious and original.

* The decoration of the table was attractive.

* Table arrangements made the environment difficult to navigate.

* The restaurant's chairs allowed me to sit at a comfortable distance from the table.

* The restaurant's seats were comfortable.

* Furniture (table, chair) was of high quality

* It is easy to get in and out of the seats at the restaurant.

Plate Scale: Plate is the last physical proof of consumers' impressions in a restaurant. When the academic studies shedding light into the importance of the plates were examined, it is obvious to see that plates influence consumers' preferences significantly. There is a relation between the amount of serving size of the food served to consumer and plate size. The participants were given three bowls with different size and asked to get cereal products as much as they wanted in a research carried out by Wansink and Van Ittersum (2006). Consumers took their food by preferring one of these three bottles. When the findings obtained in accordance with the consumers' preference were analyzed, it was found out that, the consumers preferring small-sized bowl filled and consumed $77 \%$, consumers filling, choosing middle-sized bowl consumed $74 \%$, and lastly, consumers who preferred big-sized bowls filled and consumed $64 \%$. In other words, the research unveiled those consumers who chose big sized bowl made consumption $66,6 \%$ more than the consumers preferring a small-sized bowl. Wansink and Cheney (2005) uncovered that when consumers used big-sized tables, they usually took $53 \%$ more food and they consumed 59 $\%$ more food they consumed in comparison with the food consumed in small-sized plates. The scale for plate was developed through the scale applied in the research carried out by Mil, (2012).The expressions or items involved in the scale are as following;

* The plates/dishes were smaller than normal.

* The utensils/cutlery were suitable to the courses. 
Investigation of Physical Environment as a Part of Micro Dimension in Restaurants: A Study on Local Consumers

Neslihan ÇETINKAYA, Mehmet Yavuz ÇETINKAYA

* The utensils/cutlery were of high quality.

* The utensils/cutlery are modern.

* The color of the utensils/cutlery was attractive.

* The table was set up with appropriate glasses and utensils for all courses.

* Glasses and utensils were unhygienic.

The questionnaire form was developed by evaluating the previously used scales was applied to consumers who were living in the city center of Erzurum and had habit such as eating out. In this vein, the population of the study composes the local people dwelling in Erzurum. In order to determine sampling size, the view of DeVellis (2014) was taken into consideration. According to DeVellis (2014) the number of the sample is expected to be between almost 5 times and 10 times more for each item involved in the scale in order to perform data analysis correctly. The total number of the items used in the scales applied in this research is 30 . In this sense, the author determined the sample size by basing on the number of items. The questionnaire form was to be applied at least 150 and up to 300 people.

\section{RESULTS}

Once the questionnaire form was developed and the sampling size was formulated, the participants were asked to fill in the questionnaire form. A total of 198 questionnaire forms were evaluated except for the ones missing data or incorrectly filled. This number seems to be acceptable in line with the view of DeVellis (2014). The questionnaire forms were applied to consumers eating out were transferred to SPSS 20.0 (Statistical Packages for the Social Sciences) and the author had the possibility to perform a number of analyses. The author ran reliability and validity analysis on the scales. Reliability Analysis is related to the measuring rate showing continuity from sample to sample (Netemeyer, Bearden and Sharma 2003:10). For reliability analysis, there are various methods such as (Cronbach Alpha, Split Half, Guttmann Parallel, and Strict Parallel). However, Cronbach Alpha internal consistency value is the most widely used method used in the reliability of the scales (DeVellis, 2003:27). Depending on Cronbach's Alpha, the reliability of the scale is interpreted as following (Kalayc1, 2005: 405).

$* \leq \alpha<0.40$ scale is not reliable.

* $0.40 \leq \alpha<0.60$ reliability of the scale is low.

* $\quad 0.60 \leq \alpha<0.80$ scale is highly reliable

* $\quad 0.80 \leq \alpha<1.00$ scale is extremely reliable.

Cronbach's Alpha Coefficients were calculated as an indicator of the internal consistency and homogeneity of all scale items and findings were indicated in Table 2.

Table 2. The Internal Consistency and Homogeneity Indicators of Scale Items

\begin{tabular}{c|c|c|c|c|c|c}
\hline Mean & $\begin{array}{c}\text { Std. } \\
\text { Deviation }\end{array}$ & $\begin{array}{c}\text { Scale mean } \\
\text { if item } \\
\text { deleted }\end{array}$ & $\begin{array}{c}\text { Scale } \\
\text { Variance if } \\
\text { item deleted }\end{array}$ & $\begin{array}{c}\text { Squared } \\
\text { Multiple } \\
\text { Correlation }\end{array}$ & $\begin{array}{c}\text { Cronbach's } \\
\text { Alpha if item } \\
\text { deleted }\end{array}$ \\
\hline Q1 & 1.4822 &, 71138 & 54,2538 & 147,599 &, 364 &, 878 \\
\hline
\end{tabular}




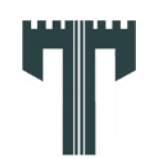

Gastroia: Journal of Gastronomy and Travel Research, Vol. 4, Issue 2, pp.,218-250 , 2020 Investigation of Physical Environment as a Part of Micro Dimension in Restaurants: A Study on Local Consumers

Neslihan ÇETINKAYA, Mehmet Yavuz ÇETINKAYA

\begin{tabular}{|c|c|c|c|c|c|c|}
\hline $\mathbf{Q 2}$ & 3,3959 & 1,27599 & 52,3401 & 156,307 &, 153 &, 894 \\
\hline Q3 & 1,6701 & ,80036 & 54,0660 & 146,052 & ,388 & ,877 \\
\hline Q4 & 3,3147 & 1,31414 & 52,4213 & 149,490 & ,286 & ,889 \\
\hline Q5 & 1,4619 & ,66611 & 54,2741 & 145,292 &, 583 & ,875 \\
\hline Q6 & 2,0761 & 1,03475 & 53,6599 & 146,491 & ,298 &, 881 \\
\hline Q7 & 1,8274 & ,93714 & 53,9086 & 148,981 & ,240 &, 882 \\
\hline Q8 & 1,2893 & ,56473 & 54,4467 & 148,085 &, 579 & ,877 \\
\hline Q9 & 1,8832 & ,86304 & 53,8528 & 140,198 & 7,562 & ,872 \\
\hline Q10 & 1,6802 & ,81708 & 54,0558 & 145,706 & ,463 & ,877 \\
\hline Q11 & 1,3959 & ,59383 & 54,3401 & 146,562 & ,597 & ,876 \\
\hline Q12 & 1,5888 & ,72032 & 54,1472 & 143,912 & 594 & ,874 \\
\hline Q13 & 2,2995 & 1,08640 & 53,4365 & 136,737 & ,649 & ,871 \\
\hline Q14 & 1,5381 & ,69607 & 54,1980 & 144,751 & 562 & ,875 \\
\hline Q15 & 2,0761 & ,97901 & 53,6599 & 140,083 & ,620 & ,873 \\
\hline Q16 & 1,8325 & ,94078 & 53,9036 & 141,669 & ,617 & ,874 \\
\hline Q17 & 2,3706 & 1,13827 & 53,3655 & 136,223 & ,634 & ,871 \\
\hline Q18 & 2,4924 & 1,12313 & 53,2437 & 138,093 & ,630 & ,873 \\
\hline Q19 & 2,7005 & 1,21498 & 53,0355 & 135,922 & ,622 & ,872 \\
\hline Q20 & 1,9797 & ,96341 & 53,7563 & 137,859 & ,654 &, 870 \\
\hline Q21 & 1,1117 & ,34658 & 54,6244 & 154,634 & , 105 &, 883 \\
\hline Q22 & 1,5838 & ,70663 & 54,1523 & 144,997 & 504 &, 875 \\
\hline Q23 & 1,4213 & ,64693 & 54,3147 & 149,666 & ,399 &, 880 \\
\hline Q24 & 1,8020 & ,99816 & 53,9340 & 142,531 & ,478 &, 876 \\
\hline Q25 & 1,3452 & ,51769 & 54,3909 & 148,658 & ,499 &, 878 \\
\hline Q26 & 1,3959 & ,60236 & 54,3401 & 147,328 & ,631 & ,877 \\
\hline Q27 & 1,5584 & ,68727 & 54,1777 & 145,177 & ,567 &, 875 \\
\hline Q28 & 1,7563 & ,81536 & 53,9797 & 152,306 & ,167 & ,884 \\
\hline
\end{tabular}




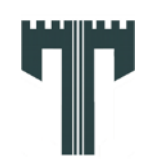

Gastroia: Journal of Gastronomy and Travel Research, Vol. 4, Issue 2, pp.,218-250 , 2020

Investigation of Physical Environment as a Part of Micro Dimension in Restaurants: A Study on Local Consumers

Neslihan ÇETINKAYA, Mehmet Yavuz ÇETINKAYA

\begin{tabular}{c|c|c|c|c|c|c}
\hline Q29 & 1,5990 &, 69002 & 54,1371 & 145,292 &, 574 &, 875 \\
\hline Q30 & 1,8071 &, 82273 & 53,9289 & 149,842 &, 216 &, 882 \\
\hline \multirow{2}{*}{ Scale's } & Mean & Std. & Variance & $\begin{array}{c}\text { Number of } \\
\text { Items }\end{array}$ & $\begin{array}{c}\text { Cronbach's } \\
\text { Alpha }\end{array}$ \\
\cline { 2 - 6 } & 55,7360 & 12,44053 & 154,767 & 30 &, 881 \\
\hline
\end{tabular}

According to Table 2, there is no item found out with a negative total item correlation (Squared Multiple Correlation) in any size of the scales. Besides, the author decided not to remove the items with a low level of reliability because Cronbach's Alpha showing reliability level was highly reliable. Participants' responses to five different scales used in order to have detailed data on scales are considered to be examined through descriptive statistics. Table 3 presents the values that involve minimum, maximum, mean and standard deviation which were determined for each scale.

Table 3. Descriptive Statistics Related to Scales

\begin{tabular}{c|c|c|c|c|c|c|c}
\hline Scale & $\mathbf{N}$ & Minimum & Maximum & Mean & $\begin{array}{c}\text { Std. } \\
\text { Deviation }\end{array}$ & $\begin{array}{c}\text { Cronbach } \\
\text { Alpha }\end{array}$ & $\begin{array}{c}\text { Variable } \\
\text { Number }\end{array}$ \\
\hline Seating Place & 197 & 1,00 & 4,00 & 2,46 &, 592 &, 465 & 4 \\
\hline Table & 197 & 1,00 & 4,30 & 1,70 &, 484 &, 793 & 10 \\
\hline Plate & 197 & 1,00 & 4,57 & 2,08 &, 729 &, 857 & 7 \\
\hline Ambiance & 197 & 1,00 & 4,40 & 1,50 &, 488 &, 717 & 5 \\
\hline Aesthetic & 197 & 1,00 & 3,00 & 1,68 &, 464 &, 499 & 5 \\
\hline
\end{tabular}

According to Table 3, there are differences in the mean values of the scales. Mean values can be expressed as to what extent participants perceive or approach to each dimension positively and negatively. In this case, it can be said that the level of participation in the expressions or items involved in seating place and plate scales. Standard Deviation value gives idea explaining to what extent observation values differ from mean values. When the values of standard deviation are examined, it is obvious to see that the highest standard deviation value belongs to the plate scale. In addition, Table 3 shows that the number of variables involved in the scales and their reliability analysis. In reliability analysis, there are scales; plate, table, ambiance, aesthetic and seating place respectively. The scale with the highest reliability level is plate scale. In other words, it can be said that this scale is highly reliable.

Once the research scales were examined in detail, the author ran descriptive statistics in order to reveal the demographic structure of the sample. Table 4 presents descriptive statistics related to participants' demographic characteristics. 


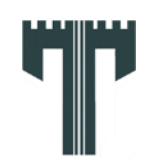

Gastroia: Journal of Gastronomy and Travel Research, Vol. 4, Issue 2, pp.,218-250 , 2020

Investigation of Physical Environment as a Part of Micro Dimension in Restaurants: A Study on Local Consumers

Neslihan ÇETINKAYA, Mehmet Yavuz ÇETINKAYA

Table 4.Participants' Demographic Characteristics

\begin{tabular}{|c|c|c|c|}
\hline \multicolumn{2}{|c|}{ Participants' Demographic Characteristics } & $\mathbf{N}$ & $\%$ \\
\hline \multirow{2}{*}{ Gender } & Male & 111 & 56,3 \\
\hline & Female & 86 & 43,7 \\
\hline \multirow{8}{*}{ Age Group } & 18 and under & 5 & 2,5 \\
\hline & $19-24$ & 60 & 30,5 \\
\hline & $25-31$ & 64 & 32,5 \\
\hline & $32-38$ & 32 & 16,2 \\
\hline & $39-45$ & 12 & 6,1 \\
\hline & $46-52$ & 12 & 6,1 \\
\hline & $53-59$ & 7 & 3,6 \\
\hline & 60 and over & 5 & 2,5 \\
\hline \multirow{5}{*}{ Educational Qualification } & Secondary School & 8 & 4,1 \\
\hline & High School & 14 & 7,1 \\
\hline & Two-year Degree & 16 & 8,1 \\
\hline & Bachelor Degree & 91 & 46,2 \\
\hline & Master and/or Doctoral Degree & 68 & 34,5 \\
\hline \multirow{3}{*}{ Time Spent for Eating } & Less than 30 minutes & 48 & 24,4 \\
\hline & Nearly 1 hour & 102 & 51,8 \\
\hline & More than 1 Hour & 47 & 23,9 \\
\hline \multirow{6}{*}{$\begin{array}{l}\text { Monthly Income } \\
\text { (Turkish Lira) }\end{array}$} & 1400 and less & 52 & 26,4 \\
\hline & $1401-2400$ & 31 & 15,7 \\
\hline & $2401-3400$ & 20 & 10,2 \\
\hline & $3401-4400$ & 32 & 16,2 \\
\hline & $4401-5400$ & 37 & 18,8 \\
\hline & 5401 and more & 25 & 12,7 \\
\hline
\end{tabular}

According to Table 4, the male participants seem to constitute more than half of the sample group. Regarding the age category of the participants, the majority of the participants that stand for the $63 \%$ were aged between 19-31-year-old. About participants' educational background, the majority of the participants had education such as Bachelor Degree and Master and/or Doctoral Degree. Further, the participants were asked to state the time they spend on eating, the findings suggest that the majority of the participants remarked that they spend almost one hour for eating. Lastly, participants' monthly income in terms of Turkish Liras was also important to understand since people with a high level of monthly income intend to eat out. The survey findings uncloak that $26 \%$ of the participants had monthly income; 1400 Turkish Liras and less. However, in general, it can be said that the participants had a high level of income.

\section{Research Hypotheses}

The research hypotheses previously formulated by the author in accordance with the research objective/s were analyzed. The study findings are presented as following below; 


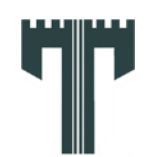

Gastroia: Journal of Gastronomy and Travel Research, Vol. 4, Issue 2, pp.,218-250 , 2020

Investigation of Physical Environment as a Part of Micro Dimension in Restaurants: A Study on Local Consumers

Neslihan ÇETINKAYA, Mehmet Yavuz ÇETINKAYA

Table 5. Correlation Analysis between Demographic Characteristics and Restaurant Aesthetic

\begin{tabular}{c|c|c|c|c}
\hline & Age Group & $\begin{array}{c}\text { Educational } \\
\text { Qualification }\end{array}$ & $\begin{array}{c}\text { Income } \\
\text { Level }\end{array}$ & $\begin{array}{c}\text { Restaurant } \\
\text { Aesthetic }\end{array}$ \\
\hline Age Group & 1 &,- 047 &, $529 * *$ &, 014 \\
Educational &, 510 &, 000 &, 845 \\
\hline Qualification & & 1 &, 019 &, 050 \\
\hline Income Level & & &, 790 &, 484 \\
\hline Restaurant & & & 1 &, 056 \\
Aesthetic & & & & \\
\hline
\end{tabular}

$\mathrm{H}^{1}$ hypothesis, which was formulated in line with research objective/s and involved the participants' demographic characteristics that involve age group, educational qualification, income level. Pearson Correlation Analysis was run to test demographic characteristics. The findings unveiled that there is no positive relation between restaurant aesthetic and the participants' demographic characteristics such as age group, educational qualification and income level. Therefore, $\mathrm{H}^{1 \mathrm{~b}}, \mathrm{H}^{1 \mathrm{c}}, \mathrm{H}^{1 \mathrm{~d}}$, hypotheses were rejected. Besides, the author ran Independent Samples t-Test to find out whether participants' gender differs in accordance with the restaurant aesthetic. Table 6 presents the findings related to this analysis.

Table 6. Independent Samples t-Test between Gender and Restaurant Aesthetic

\begin{tabular}{c|c|c|c|c|c|c}
\hline Types of Harassment & Gender & $\mathbf{N}$ & $\mathbf{X}$ & SD & $\mathbf{t}$ & $\mathbf{p}$ \\
\hline \multirow{2}{*}{ Restaurant Aesthetic } & Male & 111 & 1,72 &, 50335 & \multirow{2}{*}{1,550} & \multirow{2}{*}{, 123} \\
\cline { 2 - 6 } & Female & 86 & 1,62 &, 40538 & & \\
\hline
\end{tabular}

*The mean difference is significant at the 0,001 level.

Table 6 shows that there is no significant difference between the participants' gender and restaurant aesthetic following the findings of the Independent Samples t-Test $(p>0,001)$. Therefore, $\mathrm{H}^{1 \mathrm{a}}$ hypothesis was rejected. The Pearson Correlation Analysis and Independent Samples t-Test concluded that there is no relation between the participants' demographic characteristics and restaurant aesthetic. $\mathrm{H}^{1}$ and the sub-hypotheses were all rejected. In this vein, it could be said that there is no relation between the participants' demographic characteristics who purchase service from restaurants and restaurant aesthetic. 


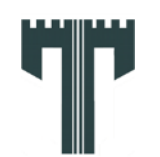

Gastroia: Journal of Gastronomy and Travel Research, Vol. 4, Issue 2, pp.,218-250, 2020

Investigation of Physical Environment as a Part of Micro Dimension in Restaurants: A Study on Local Consumers

Neslihan ÇETINKAYA, Mehmet Yavuz ÇETINKAYA

Table 7. Correlation Analysis between Demographic Characteristics and Restaurant Ambiance

\begin{tabular}{c|c|c|c|c}
\hline & Age Group & $\begin{array}{c}\text { Educational } \\
\text { Qualification }\end{array}$ & $\begin{array}{c}\text { Income } \\
\text { Level }\end{array}$ & $\begin{array}{c}\text { Restaurant } \\
\text { Ambiance }\end{array}$ \\
\hline Age Group & 1 &,- 047 &, $529 * *$ &,- 001 \\
& &, 510 &, 000 &, 983 \\
\hline $\begin{array}{c}\text { Educational } \\
\text { Qualification }\end{array}$ & & 1 &, 019 &,- 008 \\
\hline Income Level & & &, 790 &, 911 \\
\hline Restaurant & & & 1 &, 018 \\
Ambiance & & & & 1 \\
\hline
\end{tabular}

$\mathrm{H}^{2}$ hypothesis, which was developed in line with research objective/s and involved the participants' demographic characteristics that include age group, educational qualification and income level. Pearson Correlation Analysis was run to test demographic characteristics. The findings uncloaked that there is no positive relation between restaurant ambiance and the participants' demographic characteristics such as age group, educational qualification and income level. Therefore, $\mathrm{H}^{2 \mathrm{~b}}, \mathrm{H}^{2 \mathrm{c}}, \mathrm{H}^{2 \mathrm{~d}}$, hypotheses were rejected. In addition, the author ran Independent Samples t-Test to find out whether participants' gender differs in accordance with the restaurant ambiance. Table 8 presents the findings related to this analysis.

Table 8. Independent Samples t-Test between Gender and Restaurant Ambiance

\begin{tabular}{c|c|c|c|c|c|c}
\hline Variable & Gender & $\mathbf{N}$ & $\mathbf{X}$ & $\mathbf{S D}$ & $\mathbf{T}$ & $\mathbf{p}$ \\
\hline \multirow{2}{*}{ Restaurant Ambient } & Male & 111 & 1,58 &, 56475 & \multirow{2}{*}{2,390} & \multirow{2}{*}{, 018} \\
\cline { 2 - 5 } & Female & 86 & 1,41 &, 34873 & & \\
\hline
\end{tabular}

*The mean difference is significant at the 0,001 level.

Table 8 shows that there is no significant difference between the participants' gender and restaurant ambiance following the findings of the Independent Samples t-Test ( $>>0,001)$. Therefore, $\mathrm{H}^{2 \mathrm{a}}$ hypothesis was rejected. The Pearson Correlation Analysis and Independent Samples t-Test concluded that there is no relation between the participants' demographic characteristics and restaurant ambiance. $\mathrm{H}^{2}$ and the sub-hypotheses were all rejected. In this sense, it could be said that there is no relation between the participants' demographic characteristics who purchase service from restaurants and restaurant ambiance. 


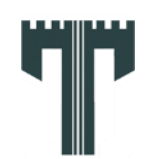

Gastroia: Journal of Gastronomy and Travel Research, Vol. 4, Issue 2, pp.,218-250 , 2020

Investigation of Physical Environment as a Part of Micro Dimension in Restaurants: A Study on Local Consumers

Neslihan ÇETINKAYA, Mehmet Yavuz ÇETINKAYA

Table 9. Correlation Analysis between Demographic Characteristics and Seating Place Preference

\begin{tabular}{c|c|c|c|c}
\hline & Age Group & $\begin{array}{c}\text { Educational } \\
\text { Qualification }\end{array}$ & $\begin{array}{c}\text { Income } \\
\text { Level }\end{array}$ & $\begin{array}{c}\text { Seating Place } \\
\text { Preference }\end{array}$ \\
\hline Age Group & 1 &,- 047 &, $529 * *$ &, 038 \\
\hline $\begin{array}{c}\text { Educational } \\
\text { Qualification }\end{array}$ &, 510 &, 000 &, 599 \\
\hline $\begin{array}{c}\text { Income Level } \\
\text { Preference }\end{array}$ & & 1 &, 019 &, $\mathbf{1 9 2 * *}$ \\
\hline Seating Place & & & 1 &, 007 \\
\hline
\end{tabular}

$\mathrm{H}^{3}$ hypothesis, which was developed in line with research objective/s and involved the participants' demographic characteristics that involve age group, educational qualification and, income level. Pearson Correlation Analysis was run to test demographic characteristics. The findings uncovered that there is no positive relation between seating place preference and the participants' demographic characteristics such as age group and income level. On the other hand, there is a positive relation between seating place preference and demographic characteristics such as educational qualification. Therefore, it may be interpreted that participants mind or care about the location of the table in the restaurants more and even might agree to pay more to be seated in a better-placed table in the restaurants depending on their educational qualification. In this sense, $\mathrm{H}^{3 \mathrm{~b}}$ and $\mathrm{H}^{3 \mathrm{~d}}$ hypotheses were rejected while $\mathrm{H}^{3 \mathrm{c}}$ hypothesis was accepted. In addition to this, the author ran Independent Samples t-Test to find out whether participants' gender differs in accordance with the seating place preference in restaurants. Table 10 presents the findings related to this analysis.

Table 10. Independent Samples t-Test between Gender and Seating Place Preference

\begin{tabular}{c|c|c|c|c|c|c}
\hline Variable & Gender & $\mathbf{N}$ & $\mathbf{X}$ & $\mathbf{S D}$ & $\mathbf{t}$ & $\mathbf{p}$ \\
\hline \multirow{2}{*}{ Seating Place Preference } & Male & 111 & 2,4144 &, 66785 & \multirow{2}{*}{$-1,384$} & \multirow{2}{*}{, 168} \\
\cline { 2 - 5 } & Female & 86 & 2,5320 &, 47403 & & \\
\hline
\end{tabular}

*The mean difference is significant at the 0,001 level.

Table 10 shows that there is no significant difference between the participants' gender and seating place preference in restaurants following the findings of the Independent Samples $\mathrm{t}$-Test $(\mathrm{p}>0,001)$. Therefore, $\mathrm{H}^{3 \mathrm{a}}$ hypothesis was rejected. 


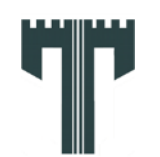

Gastroia: Journal of Gastronomy and Travel Research, Vol. 4, Issue 2, pp.,218-250 , 2020

Investigation of Physical Environment as a Part of Micro Dimension in Restaurants: A Study on Local Consumers

Neslihan ÇETINKAYA, Mehmet Yavuz ÇETINKAYA

Table 11. Correlation Analysis between Demographic Characteristics and Table Evaluation

\begin{tabular}{c|c|c|c|c}
\hline & Age Group & $\begin{array}{c}\text { Educational } \\
\text { Qualification }\end{array}$ & $\begin{array}{c}\text { Income } \\
\text { Level }\end{array}$ & $\begin{array}{c}\text { Table } \\
\text { Evaluation }\end{array}$ \\
\hline Age Group & 1 &,- 047 &, $529 * *$ &,- 103 \\
\hline $\begin{array}{c}\text { Educational } \\
\text { Qualification }\end{array}$ & &, 510 &, 000 &, 148 \\
\hline Income Level & & 1 &, 019 &, 055 \\
& & &, 790 &, 445 \\
\hline Table & & & 1 &,- 073 \\
Evaluation & & & & 1 \\
\hline
\end{tabular}

$\mathrm{H}^{4}$ hypothesis, which was developed in line with research objective/s and involved the demographic characteristics that include age group, educational qualification and income level. Pearson Correlation Analysis was run to test demographic characteristics. The findings unveiled that there is no relation between the participants' demographic characteristics and table evaluation. Therefore, it can be said that participants do not pay any attention/do not care their table to be comfortable, to be of high quality; to be suitable for/convenient to interview or talk with others and to be clean. In this sense, $\mathrm{H}^{4 \mathrm{~b}}, \mathrm{H}^{4 \mathrm{c}}, \mathrm{H}^{4 \mathrm{~d}}$ hypotheses were rejected. Furthermore, the author ran Independent Samples t-Test to find out whether participants' gender differs in accordance with the table evaluation. Table 12 presents the findings related to this analysis.

Table 12. Independent Samples t-Test between Gender and Table Evaluation

\begin{tabular}{c|c|c|c|c|c|c}
\hline Variable & Gender & $\mathbf{N}$ & $\mathbf{X}$ & $\mathbf{S D}$ & $\mathbf{t}$ & $\mathbf{p}$ \\
\hline \multirow{3}{*}{ Table Evaluation } & Male & 111 & 1,6829 &, 55839 & & \multirow{2}{*}{, 487} \\
\cline { 2 - 6 } & Female & 86 & 1,7314 &, 36791 &,- 697 & \multirow{2}{*}{} \\
\hline
\end{tabular}

*The mean difference is significant at the 0,001 level.

Table 12 shows that there is no significant difference between the participants' gender and table evaluation in restaurants following the findings of the Independent Samples t-Test ( $p>0,001)$. Therefore, $\mathrm{H}^{4 a}$ hypothesis was rejected. 


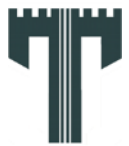

Gastroia: Journal of Gastronomy and Travel Research, Vol. 4, Issue 2, pp.,218-250 , 2020

Investigation of Physical Environment as a Part of Micro Dimension in Restaurants: A Study on Local Consumers

Neslihan ÇETINKAYA, Mehmet Yavuz ÇETINKAYA

Table 13. Correlation Analysis between Demographic Characteristics and Plate Evaluation

\begin{tabular}{c|c|c|c|c}
\hline & Age Group & $\begin{array}{c}\text { Educational } \\
\text { Qualification }\end{array}$ & $\begin{array}{c}\text { Income } \\
\text { Level }\end{array}$ & Plate Evaluation \\
\hline Age Group & 1 &,- 047 &, $529 * *$ &,- 139 \\
&, 510 &, 000 &, 052 \\
\hline $\begin{array}{c}\text { Educational } \\
\text { Qualification }\end{array}$ & & 1 &, 019 &, 082 \\
\hline Income Level & & & 1 &, 254 \\
\hline Plate Evaluation & & &, $049 * *$ &, 490 \\
\hline
\end{tabular}

According to Table 13, the findings of the Pearson Correlation Analysis on the relation between the participants' demographic characteristics and plate evaluation. On one hand, the findings uncovered that there is no relation between the participants' demographic characteristics such as age $\left(\mathrm{H}^{5 b}\right)$ and educational qualification $\left(\mathrm{H}^{5 \mathrm{c}}\right)$ and plate evaluation. On the other hand, the findings revealed that there is a positive significant relation between demographic characteristics such as income level $\left(\mathrm{H}^{5 \mathrm{~d}}\right)$. Therefore, it may be commented that when the participants' income level increases, they expect the plates/dishes to be suitable for them, the utensils/cutlery to be suitable to the courses and to have high quality, to be modern and to be hygienic. Moreover, the author ran Independent Samples t-Test to find out whether participants' gender differs in accordance with the plate evaluation. Table 14 presents the findings related to this analysis.

Table 14. Independent Samples t-Test between Gender and Plate Evaluation

\begin{tabular}{c|c|c|c|c|c|c}
\hline Variable & Gender & $\mathbf{N}$ & $\mathbf{X}$ & $\mathbf{S D}$ & $\mathbf{t}$ & $\mathbf{p}$ \\
\hline \multirow{2}{*}{ Table Evaluation } & Male & 111 & 2,0425 &, 79763 & & \multirow{2}{*}{, 408} \\
\cline { 2 - 5 } & Female & 86 & 2,1296 &, 63307 &,- 830 & \\
\hline
\end{tabular}

*The mean difference is significant at the 0,001 level.

Table 14 shows that there is no significant difference between the participants' gender and plate evaluation in restaurants following the findings of the Independent Samples t-Test ( $>>0,001)$. Therefore, $\mathrm{H}^{5 a}$ hypothesis was rejected. 
Gastroia: Journal of Gastronomy and Travel Research, Vol. 4, Issue 2, pp.,218-250 , 2020

Investigation of Physical Environment as a Part of Micro Dimension in Restaurants: A Study on Local Consumers

Neslihan ÇETINKAYA, Mehmet Yavuz ÇETINKAYA

Table 15. Correlation Analysis between Restaurant Aesthetic, Restaurant Ambiance and Seating Place Preference

\begin{tabular}{c|c}
\hline & Seating Place Preference \\
\hline Restaurant Aesthetic &, $\mathbf{2 1 7 * *}$ \\
&, 002 \\
\hline Restaurant Ambiance &, 121 \\
&, 091 \\
\hline
\end{tabular}

According to Table 15, the findings of the Pearson Correlation Analysis on the relation between the restaurant aesthetic, restaurant ambiance, and seating place preference. The findings uncover that there is a positive significant relation between restaurant aesthetic and seating place preference. Therefore, it can be commented that the factors such as; the architecture used in the restaurants gives an attractive character, the decoration of the restaurants in an attractive fashion and the interior de'cor of the restaurants in an attractive way encourage participants to prefer being seated and eat in the restaurants and to look for a seating place since they like the restaurant aesthetic. In this vein, $\mathrm{H}^{6}$ hypothesis was accepted. Per contra, the findings conclude that there was no significant relation between restaurant ambiance and seating place preference. In this sense, it can be commented that the factors such as; the overall lighting level of the restaurants' environment is appropriate, the temperature in the restaurants is pleasant, the aroma in the restaurants is pleasant seemed not to play any role on the participants' choice of the restaurants. In this sense, $\mathrm{H}^{7}$ hypothesis was rejected.

Table 16. Correlation Analysis between Table, Plate Evaluation and Seating Place Preference

\begin{tabular}{l|c|c}
\hline & Table Evaluation & Plate Evaluation \\
\hline \multirow{2}{*}{ Seating Place Preference } & $\mathbf{2 9 0 * *}$ &, 121 \\
\cline { 2 - 3 } & $\mathbf{, 0 0 0}$ &, 091 \\
\hline
\end{tabular}

According to Table 16, the findings of the Pearson Correlation Analysis on the relation between the table and plate evaluation and seating place preference. The findings uncloak that; there is a positive significant relation between table evaluation and seating place preference. In other words, the participants who care about the location of the table following the seating place preference want to have a table, which is better, cleaner and more comfortable one physically. Therefore, $\mathrm{H}^{8}$ hypothesis was accepted. In other respects, the findings uncovered that there is no relation between plate evaluation and seating place preference. In this vein, $\mathrm{H}^{9}$ hypothesis was rejected. 


\section{$\nabla$}

Gastroia: Journal of Gastronomy and Travel Research, Vol. 4, Issue 2, pp.,218-250 , 2020

Investigation of Physical Environment as a Part of Micro Dimension in Restaurants: A Study on Local Consumers

Neslihan ÇETINKAYA, Mehmet Yavuz ÇETINKAYA

One of the objectives of this research is to find out the influence of physical areas/environments on consumers. For this reason, the percentages/rates of the responses provided by the participants to the questions pursuing restaurant aesthetic, restaurant ambiance, seating place preference, table and plate evaluation are presented to unveil their opinions in Table 17.

Table 17. Participants' Tendency on Restaurants' Physical Areas

\begin{tabular}{|c|c|c|c|c|c|c|}
\hline & & 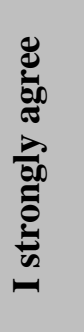 & 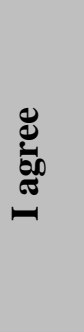 & 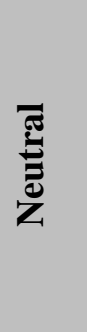 & 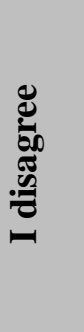 & 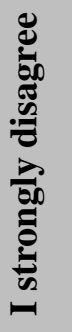 \\
\hline \multirow{4}{*}{ 苞 } & $\begin{array}{l}\text { This restaurant's architecture gave it an attractive } \\
\text { character }\end{array}$ & 52,8 & 40,6 & 5,1 & 1 & 0,5 \\
\hline & This restaurant was decorated in an attractive fashion & 42,1 & 45,7 & 7,1 & 4,6 & 0,5 \\
\hline & $\begin{array}{l}\text { The use of color in the de'cor scheme adds } \\
\text { excitement to this restaurant environment }\end{array}$ & 48,7 & 45,7 & 2,5 & 3 & 0 \\
\hline & The interior de' cor of this restaurant was attractive & 40,1 & 44,2 & 10,7 & 5,1 & 0 \\
\hline \multirow{5}{*}{ 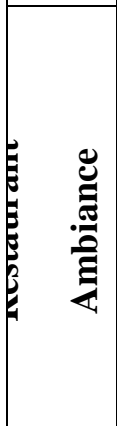 } & $\begin{array}{l}\text { The overall lighting level in this restaurant } \\
\text { environment was appropriate }\end{array}$ & 51,3 & 41,6 & 5,1 & 1,5 & 0,5 \\
\hline & The temperature in this restaurant was comfortable & 63,5 & 33 & 2,5 & 0 & 1 \\
\hline & The aroma in this restaurant was pleasant & 46,7 & 38,1 & 6,6 & 5,6 & 3 \\
\hline & $\begin{array}{l}\text { The background music played overhead, made this } \\
\text { restaurant a more enjoyable place }\end{array}$ & 67 & 32 & 0,5 & 0,5 & 0 \\
\hline & $\begin{array}{l}\text { The restaurant environment was positive, and left me } \\
\text { with very good feelings }\end{array}$ & 64,5 & 33 & 1,5 & 0,5 & 0,5 \\
\hline \multirow{4}{*}{ 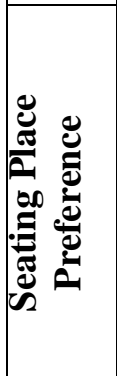 } & I care a lot about location of my table in a restaurant & 59,9 & 35,5 & 2 & 1,5 & 1 \\
\hline & $\begin{array}{l}\text { I do not mind sitting at a table around with high } \\
\text { traffic around and less privacy }\end{array}$ & 9,1 & 19,3 & 16,2 & 34,6 & 20,8 \\
\hline & $\begin{array}{l}\text { I prefer highly private tables located against a wall or } \\
\text { a window }\end{array}$ & 47,2 & 44,2 & 4,1 & 3,6 & 1 \\
\hline & I am willing to pay more for a better located table & 13,2 & 16,2 & 15,7 & 35,5 & 19,3 \\
\hline \multirow{3}{*}{ 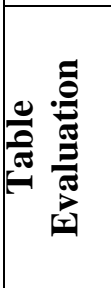 } & The table was comfortable & 59,9 & 37,1 & 0,5 & 2 & 0,5 \\
\hline & $\begin{array}{l}\text { Table lining (table cloth, napkins, etc.) was of high } \\
\text { quality }\end{array}$ & 33,5 & 40,1 & 13,2 & 11,7 & 1,5 \\
\hline & $\begin{array}{l}\text { Table arrangements were conducive to a pleasant } \\
\text { conversation with others }\end{array}$ & 41,6 & 44,2 & 6,1 & 6,1 & 2 \\
\hline
\end{tabular}




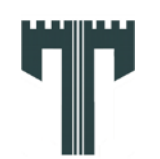

Gastroia: Journal of Gastronomy and Travel Research, Vol. 4, Issue 2, pp.,218-250 , 2020

Investigation of Physical Environment as a Part of Micro Dimension in Restaurants: A Study on Local Consumers

Neslihan ÇETINKAYA, Mehmet Yavuz ÇETINKAYA

\begin{tabular}{|l|l|c|c|c|c|c|}
\hline & The table was appearing neat, precious and original & 74,6 & 23,4 & 1 & 0,5 & 0,5 \\
\cline { 2 - 5 } & The decoration of the table was attractive & 37,6 & 44,7 & 10,2 & 7,1 & 0,5 \\
\hline $\begin{array}{l}\text { Table arrangements made the environment difficult } \\
\text { to navigate }\end{array}$ & 47,2 & 43,7 & 4,1 & 4,1 & 1 \\
\hline $\begin{array}{l}\text { The restaurant's chairs allowed me to sit at a } \\
\text { comfortable distance from the table }\end{array}$ & 64 & 34 & 1 & 0,5 & 0,5 \\
\hline $\begin{array}{l}\text { The restaurant's seats were comfortable } \\
\text { Furniture (table, chair) was of high quality }\end{array}$ & 51,3 & 41,6 & 4,6 & 2 & 0,5 \\
\hline $\begin{array}{l}\text { It is easy to get in and out of the seats at the } \\
\text { restaurant }\end{array}$ & 53,8 & 42,1 & 1 & 2,5 & 0,5 \\
\hline & The plates/dishes were smaller than normal. & 27,9 & 49,7 & 12,2 & 7,1 & 3 \\
\hline $\begin{array}{l}\text { The utensils/cutlery were suitable to the courses } \\
\text { The utensils/cutlery were of high quality }\end{array}$ & 42,1 & 42,6 & 6,6 & 7,1 & 1,5 \\
\hline & 24,9 & 37,1 & 18,3 & 15,7 & 4,1 \\
\hline
\end{tabular}

According to Table 17, it could be said that consumers generally pay attention to the restaurant aesthetic. Because $93,4 \%$ of the participants stated that they agree with the fact that the architecture makes the restaurant more attractive. Besides, the participants, $87,8 \%$ of them seemed to give importance to the decoration of the restaurant in an attractive way. The consumers with $94,4 \%$ rate agree with the fact that the use of color in the de'cor scheme adds excitement to the restaurant environment. Lastly, the consumers consider the interior de'cor of the restaurant to be attractive as important. Therefore, it can be commented that restaurant aesthetic plays a fundamental role on the consumers' preference of the restaurant.

Regarding the participants' opinions on restaurant ambiance, it can be concluded that the participants, 97,5\% of them agree with the fact that it is important that the atmosphere of the restaurant should be positive and to leave the restaurant with good feelings. Furthermore, the participants who represent $92,9 \%$ care about the overall lightening level to be appropriate followed by $96,5 \%$ that stand for the participants who consider the temperature to be comfortable as important, $84,8 \%$ of the participants stated that they care about the aroma in the restaurant to be pleasant. Lastly, the participants, $99 \%$ of them thought that the background music played overhead makes the restaurant to be a more enjoyable place. Therefore, it can be commented that consumers consider the restaurant ambiance. 


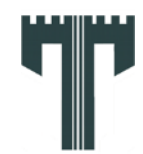

Gastroia: Journal of Gastronomy and Travel Research, Vol. 4, Issue 2, pp.,218-250 , 2020

Investigation of Physical Environment as a Part of Micro Dimension in Restaurants: A Study on Local Consumers

Neslihan ÇETINKAYA, Mehmet Yavuz ÇETINKAYA

About the seating place preference of the participants, 95,4\% of the participants remarked that they consider the location of their tables in the restaurants important followed by 91,4 $\%$ that stand for the participants who stated that they would prefer a table located against a wall or a window. However, no matter the consumers would want to be seated at tables which were located in the best place of the restaurants, only $29,4 \%$ of the participants would agree to pay more for the better-located tables. The rest of the participants seemed to be seated at tables located in the best places in the restaurants but not willing to pay more money for the location of the tables. Therefore, money can be interpreted to be an important criterion. Because every consumer would want to spend dining experience and pleasure in a place where s/he can spend time comfortably.

The findings of the participants' table and plate evaluation which constitute the next phase of the seating place preference of the consumers revealed that; the participants $97 \%$ of them reported that they would want their table to be comfortable in the restaurants they prefer/will prefer followed by $85,8 \%$ that account for the participants who would care table arrangements to be conducive to a pleasant conversation with others, $98 \%$ of the participants would consider the table to be clean, precious and original important and 90,9 of the participants remarked that table arrangements should not be made the environment difficult to navigate. The participants, $98 \%$ of them stated that they would take into consideration that restaurant chairs should allow consumers to sit at a comfortable distance from the table. In this sense, it can be said that the criterion such as a comfortable and high-quality table, comfortable chairs have importance for the consumers. In addition, on one hand, the participants, $84,7 \%$ of them would regard the utensils/cutlery to be suitable to the courses as important, on the other hand, $98,9 \%$ of the participants reported that they would care about the glasses and utensils to be hygienic. In general, it can be concluded that consumers would prefer the utensils/cutlery to be of high quality when their plate evaluation is taken into consideration.

\section{DISCUSSION AND CONCLUSION}

The eating issue has started to be regarded as a life quality rather than to meet a necessity in today's world. The increase of the people' living standards has made them take some criterion into consideration when to make a choice of the restaurants in the market. In this case, the necessity emerged that the restaurants should make some differentiation while meeting the demands of the consumers in order to have a competitive advantage. The restaurants should have information about the profile of the consumers in the target market in order to fulfill this requirement and they should work on consumer-focused activities/works and thus try to achieve their objectives. Therefore, the physical areas of the restaurants should be designed in a way that will bring a positive contribution to consumers' consumption feeling and their dining or eating experience. In this sense, the criterion/factors such as restaurant aesthetics, restaurant ambiance, seating place preference, table and utensils such as plate, glass, etc. ought to be regarded as drivers that may influence consumers. Depending on this data, this study aims to investigate whether the physical areas in the restaurants have an impact on consumers or not and to find out the participants' experience to eat in a physically better restaurant. 


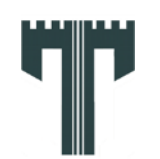

Gastroia: Journal of Gastronomy and Travel Research, Vol. 4, Issue 2, pp.,218-250 , 2020

Investigation of Physical Environment as a Part of Micro Dimension in Restaurants: A Study on Local Consumers

Neslihan ÇETINKAYA, Mehmet Yavuz ÇETINKAYA

First of all, the internal consistency and homogeneity indicators were calculated in accordance with the study objectivities. Following the applied analysis, it was found out that there was no item with a negative value. Then, the descriptive statistics were carried out to find out the values such as minimum, maximum, standard deviation, and Cronbach Alpha. After obtaining more data regarding the scales, the author unveiled the demographic characteristics of the participants. The majority of the participants were male, have age category such as 25-31, with an educational background Bachelor Degree and have monthly income 1400 Turkish Liras and lower. In addition, the majority of the participants, more than half of the sampling group seemed to spend approximately one hour for eating.

The author analyzed the previously-formulated hypotheses to find out the main objective of the study via conducting Correlation and Independent Samples t-Test. The research model, developed in accordance with the research objectives, the relation was generated between participants' demographic characteristics and restaurant aesthetics and restaurant ambiance. However, the analyzing process of the hypotheses formulated as a result of these relations uncovered that there was only a positive significant relation between participants' educational background and seating place preference. Besides, the author thought that there would be a positive significant relation between restaurant aesthetics, restaurant ambiance and seating place preference but it was found out that only aesthetics factors/drivers that restaurants have may encourage the consumers to take the next step. In other words, when the consumers like the restaurant aesthetics, then, they will go to the phase to choose the seating place. In the relation generated between the participants' seating place preference, who decided to be seated in the restaurant and table and plate evaluation, the findings uncloaked that there was only a significant positive difference between seating place preference and table evaluation. In other saying, the consumers who care about the place which they are seated also want the table to have the certain characteristics they want. However, the findings uncovered that the utensils/cutlery were not significantly related to their seating place preference.

The research also embraced the frequency analysis to uncover the impact of the physical areas on consumers in the restaurants. Following the analysis, it was found out that the consumers mostly prefer the aesthetically pleasing and attractively decorated restaurants. The consumers stating that restaurant ambiance that involves such as lightning, temperature, aroma or ador, music, etc., are also important, provided their opinions.

The consumers who like the restaurant in terms of aesthetics and ambiance seemed to move the next phase to choose the seating place preference. At this phase, the consumers highly pay attention to the table location to be seated and they mostly prefer special tables, but do not agree to pay more money to be seated at a better-located table in the restaurants. The consumers who prefer the table to be seated consciously start to make table evaluation at the next stage. In general, the consumers want the table they choose to be of high quality, clean, original and decorated attractively with comfortable tables. At this stage, the consumers who are satisfied with this aforementioned drivers care about the fact that the plates/dishes to have a normal size, to be modern and hygienic. In this case, the utensils/cutlery that will be used for eating in restaurants should be chosen carefully. 


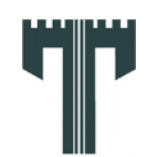

Gastroia: Journal of Gastronomy and Travel Research, Vol. 4, Issue 2, pp.,218-250 , 2020

Investigation of Physical Environment as a Part of Micro Dimension in Restaurants: A Study on Local Consumers

Neslihan ÇETINKAYA, Mehmet Yavuz ÇETINKAYA

Depending on the research findings, it can be commented that the restaurant administrators/directors should determine the important factors which possibly play important role on the restaurant selection of the consumers. The service provided in the restaurants should not be perceived as only preparing/cooking a good meal and presenting it by the administrators/directors and employees of the restaurants. Since these are compulsory requirements to fulfill, the fact that the restaurants should be designed attractively that will make consumers satisfied needs to be taken into consideration and the emphasis should be given on this as well. A proper and correct design of the restaurant aesthetics and ambiance influence the consumers positively and directly play a role on the consumers' satisfaction level and provide customer satisfaction.

Another finding of the study was the significant positive relation between the participants' educational background and seating place preference. The consumers with a good educational background pay attention to the seating arrangement and table arrangements that are far away from each other and are designed in a way that not slowing down the service flow in the restaurants they prefer. However, the owners/administrators thinking to have more profit, place more tables in the restaurants and this situation creates congestion in the seating order. In this case, the administrators should make the consumers to be seated comfortably and focus on having the profits from the customers left in a satisfied way in the long terms. In addition, the consumers who have a high level of income monthly care about factors such as plates/dishes, utensils/cutlery, glasses, etc. Therefore, all the pieces of equipment that will be used in the restaurants should be chosen in accordance with the consumers' preference, they should be of high quality, suitable to the courses in the menu and lastly, be hygienic. All these criteria are based on the owner of the restaurants to be realized. The fact that the consumers should not only be fed by the restaurants since this is not enough, the preference of the equipments needs to be done in a more careful way by thinking the image of the restaurant into consideration necessarily.

Considering the previously conducted studies, the subject was observed to be related to personal behaviors. Despite the fact that there are studies that dwelled into the physical characteristics of the restaurants, customer satisfaction, customer loyalty, and re-visit intention, the number of studies examining the whole process gradually is limited. In other words, the consumers first make a step into the restaurant and when they like the restaurant aesthetics and ambiance, they look for a place to be seated. If they find a place with the required criteria, they evaluate table and then make the evaluation of the plate on the condition that table evaluation is approved. From this point on, the author suggests the researchers willing to make further research on this subject to add the some certain topics such as customer satisfaction, customer loyalty and re-visit intention to their research model in order to find out the fact that all the processes satisfy customers as a whole. In this vein, future studies are suggested to apply different scales to the research model of this study and investigate from a more general way. 


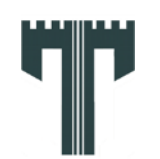

Gastroia: Journal of Gastronomy and Travel Research, Vol. 4, Issue 2, pp.,218-250 , 2020

Investigation of Physical Environment as a Part of Micro Dimension in Restaurants: A Study on Local Consumers

\section{REFERENCES}

Neslihan ÇETINKAYA, Mehmet Yavuz ÇETINKAYA

Albayrak, A. (2014). Müşterilerin Restoran Seçimlerini Etkileyen Faktörler: İstanbul Örneği, Anatolia: Turizm Araştırmaları Dergisi, 25(2): 190-201.

Arıker, Ç. (2012). Tüketicilerin Restoran Seçiminde Kullandıkları Seçim Kriterleri ile Demografik Özellikleri Arasındaki İlişki, Öneri Dergisi, 10 (38): 11-32.

Auty, S. (1992). Consumer Choice and Segmentation in the Restaurant Industry, The Service Industries Journal, 12 (3): 324-339.

Baker, J. (1987), The Role of the Environment in Marketing Services: The Consumer Perspective. In: Czepiel, J., Congram, C.A. And Shanahan, J. (Eds.), the Services Challenge: Integrating For Competitive Advantage, Chicago: American Marketing Association, 79-84.

Barta, A. (2008). Foreign Tourists' Motivation and Information Source Influencing Their Preference For Eating Out At Ethnic Restaurants in Bangkok, International Journal of Hospitality \& Tourism Administration, 9 (1): 1-17.

Becker, F. D. \& Mayo, C. (1971) Delineating Personel Distance and Territoiality, Environment and Behavior, 3: 375-381.

Bitner, M. J. (1992). Servicescapes: The Impact of Physical Surroundings on Customers and Employees, Journal of Marketing, 56: 57-71.

Charters, S. (2006). Aesthetic Products and Aesthetic Consumption: A Review, Consumption Markets \& Culture, 9(3): 235-255.

Clark, M. \& Wood, R. C. (1998). Consumer Loyalty in the Restaurant Industry: A Preliminary Exploration of the Issues, International Journal of Contemporary Hospitality Management, 10 (4): 139-144.

Cullen, P. (1994). Time, Tastes and Technology: The Evolution of Eating out, British Food Jo-urnal, 96 (10): 4-9.

DeVellis, R. (2003). Scale Development: Theory and Applications (2nd ed.). Thousand Oaks, CA: Sage.

Devellis, R. F. (2014). Ölçek Geliştirme: Kuram ve Uygulamalar. (Çev. Ed. T. Totan). Ankara: Nobel Akademik Yayıncılık.

Devrani, T. K. (2014). Müşterilerin Restoran Çalışanlarının Bahşiş Artırma Amaçlı Davranışlarına Karşı Tutumları, Dokuz Eylül Üniversitesi Íktisadi ve İdari Bilimler Fakültesi Dergisi, 29(1): 137-160.

Gold, D. L. (2002) English Nouns and Verbs Ending in -Scape, Revista Alicantina de Estudios Ingleses, 15: 79-94. 


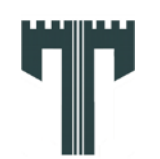

Gastroia: Journal of Gastronomy and Travel Research, Vol. 4, Issue 2, pp.,218-250 , 2020

Investigation of Physical Environment as a Part of Micro Dimension in Restaurants: A Study on Local Consumers

Neslihan ÇETINKAYA, Mehmet Yavuz ÇETINKAYA

Gregory, S. \& Kim, J., (2004). Restaurant Choice: The Role of Information. Journal of Foodservice Business Research, 7(1): 81- 95.

Güler,S. (2007). Yiyecek ve İçecek İşletmeleri İçin Rekabet Avantajı Yaratacak Stratejik Seçenekler. Araştırma İncelemeleri. Editör: Tutuncu, Ö., Anatolia Turizm Araştırmaları Dergisi, 18 (1): 101-104

Gültekin, T., Akın, G. \& Özkoçak, V. (2016), Ergonomik Restoran Tasarımında antropometrinin Önemi, Antropoloji Dergisi, 31:61-70

Ha, J. \& Jang, S. S. (2010). Effects of Service Quality and Food Quality: The Moderating Role of Atmospherics in an Ethnic Restaurant Segment. International Journal of Hospitality Management, 29 (3): 520-529.

Harrington, R. J., Ottenbacher, M. C. \& Kendall, K. W. (2011). Fine-Dining Restaurant Selection: Direct and Moderating Effects of Customer Attributes, Journal of Foodservice Business Research, 14 (3): 272-289.

Häubl, G. \& V. Trifts, 2000. Consumer Decision Making in Online Shopping Environments: The Effects of Interactive Decision Aids. Marketing Science, 19(1): 421.

Hwang, J. \& Yoon, S. (2009) Where Would You Like to Sit? Understanding Customers' Privacy-Seeking Tendencies and Seating Behaviors to Create Effective Restaurant Environments, Journal of FoodserviceBusiness Research, 12: 219-233.

Jaafar, S.N., Lumbers, M. \& Eves, A., (2009). Does Food Really Matters in the Eating out Experience in Restaurants. International Journal of Contemporary Hospitality Management, 8(2): 1-11.

Johnson, E. J. \& John W. P.(1985), Effort and Accuracy in Choice, Management Science, 31 (4): 395-414.

Kant, A. K. \& Graubard, B. I. (2004). Eating Out in America, 1987-2000: Trends and Nutritional Correlates, Preventive Medicine, 38: 243-249.

Kılınç, O. \& Çavuş, Ş. (2010). Yiyecek-Içecek Sektörüne Genel Bakış. Yıldız, Ertan (ed.), Restoran İşletmelerine Giriş. Ankara: Detay Yayıncılık.

Kim, W. G. \& Moon, Y. J. (2009). Customers' Cognitive, Emotional, and Actionable Response to the Servicescape: A Test of the Moderating Effect of the Restaurant Type, International Journal of Hospitality Management, 28: 144-156.

Kivela, J., Inbakaran, R. \& Reece, J. (1999a). Consumer Research in the Restaurant Environment. Part 2: Research Design and Analytical Methods, International Journal of Contemporary Hospitality Management, 11 (6): 269-286.

Kivela, J., Inbakaran, R. \& Reece, J. (1999b). Consumer Research in the Restaurant Environment, Part 1: A Conceptual Model of Dining Satisfaction and Return 


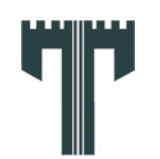

Gastroia: Journal of Gastronomy and Travel Research, Vol. 4, Issue 2, pp.,218-250 , 2020

Investigation of Physical Environment as a Part of Micro Dimension in Restaurants: A Study on Local Consumers

Neslihan ÇETINKAYA, Mehmet Yavuz ÇETINKAYA

Patronage, International Journal of Contemporary Hospitality Management, 11 (5): 205-222.

Kivela, J.; Inbakaran, R. \& Reece, J. (2000). Consumer Research in the Restaurant Environment Part 3: Analysis, Findings and Conclusions. International Journal of Contemporary Hospitality Management, 12 (1): 13 - 30.

Lewis, R.C. (1981). Restaurant Advertising: Appeals and Consumers' Intentions, Journal of Advertising Research, 21 (5): 69-74.

Lindstrom, M. (2006), Duyular ve Marka: 5 Duyuyla Güçlü Markalar Yaratmak. Çev. Ümit Şensoy. İstanbul: Optimist Yayınları.

Ma, H. (1999). Constellation of Competitive Advantage: Components and Dynamics, Management Decision, 37 (4): 348-355.

Mil, B. (2012). Alan Algısının Turistlerin Yemek Deneyimi Memnuniyetine Etkileri, Doktora Tezi, Adnan Menderes Üniversitesi: Aydın

Narine, T. \& Badrie, N. (2007). Influential Factors Affecting Food Choices of Consumers When Eating Outside the Household in Trinidad, West Indies, Journal of Food Products Marketing, 13(1): 19-29.

Netemeyer, R.G., Bearden, W. O. \& Sharma, S. (2003). Scaling procedures: issues and applications. SAGE Publications, Thousand Oaks, California

Njite, D., Dunn, G. \& Kim, L.H. (2008). Beyond Good Food: What Other Attributes Influence Consumer Preference and Selection of Fine Dining Restaurants? Journal of Foodservice Business Research, 11 (2): 237-266.

Oral, S. \& Çelik, A. (2013). Türkiye'yi Ziyaret Eden Turistlerin Estetik Deneyimleri Üzerine Bir Araştırma, İşletme Araştırmaları Dergisi, 5(4): 170-190.

Özdemir, B. (2010). Dışarıda Yemek Yeme Olgusu: Kuramsal Bir Model Önerisi, Anatolia: Turizm Araştırmaları Dergisi, 21 (2): 218-232.

Park, C. (2004). Efficient or Enjoyable? Consumer Values of Eating Out and Fast Food Restaurant Consumption in Korea, International Journal of Hospitality Management, 23: 87-94.

Pedersen, D. M. (1979) Dimensions of Privacy, Perceptual and Motor Skills, 48:12911297.

Raab, C., Mayer, K. \& Shoemaker, S. (2009). Price-Sensitivity Measurement: A Tool for Restaurant Menu Pricing, Journal of Hospitality \& Tourism Research, 33 (1): 93-105.

Robson, S. K. A, Kimes, S. E., Becker, F. D. \& Evans, G. W. (2011) Consumers' Responses to Table Spacing in Restaurants, Cornell Hospitality Quarterly, 1- 12. 


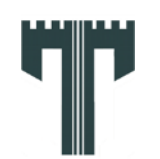

Gastroia: Journal of Gastronomy and Travel Research, Vol. 4, Issue 2, pp.,218-250 , 2020

Investigation of Physical Environment as a Part of Micro Dimension in Restaurants: A Study on Local Consumers

Neslihan ÇETINKAYA, Mehmet Yavuz ÇETINKAYA

Ryu, K. \& Han, H. (2010) Influence of the Quality of Food, Service, and Physical Environment on Customer Satisfaction and Behavioral Intention in Quick- Casual Restaurants: Moderating Role of Perceived Price, Journal of Hospitality and Tourism Research, 34(3): 310-329

Schmitt, B. \& Simonson, A. (1997). Marketing Aesthetics: The Strategic Management of Brands, Identity and Image, New York: The Free Press.

Özdevecioğlu, M. \& Erdem F. S. (2008) “İzlenim Yönetimi Davranışı: Örgütsel Açıdan Teorik Çerçeve”, Mahmut Özdevecioğlu ve Himmet Karadal (Ed.),Örgütsel Davranışta Seçme Konular: Organizasyonların Karanlık Yönleri ve Verimlilik Azaltıcı Davranışlar, İlkeYayınevi, Yayın No: 11, Ankara, ss. 33-54.

Seiter, J. S. (2007). Ingratiation and Gratuity: The Effect of Complimenting Customers on Tipping Behavior in Restaurants. Journal of Applied Social Psychology, 37:478-485. doi: 10.1111/j.1559-1816.2007.00169.x

Seiter, J. S. \& Weger, H. (2010). The Effect of Generalized Compliments, Sex of Server, and Size of Dining Party on Tipping Behavior in Restaurants. Journal of Applied Social Psychology, 40:1-12. doi: 10.1111/j.1559-1816.2009.00560.x.

Shepherd, R. (2001). Does Taste Determine Consumption? Understanding the Psychology of Food Choice, İçinde L.J. Frewer, H. Schifferstein ve E. Risvik (Editörler), People and Society. A European Perspective of Consumers' Food Choice. Berlin, Heidelberg : Springer-Verlag.

Tannahill, R. (1988). Food in History. New York: Three Rivers Press.

Türksoy, A. (1997). Yiyecek ve İçecek Hizmetleri Yönetimi, Ankara: Turhan Kitabevi Yayınları.

Vaheeduzzan A. \& Ryans J. (1995). Definition, Perspectives and Understanding of International Competitiveness: A Quest for a Common Ground, Competitiveness Review, 6 (2): 7-16

Wakefield, K.L. \& Blodgett, J.G. (1996) The Effects of the Servicescape on Customers' Behavioral Intentions in Leisure Service Setting, Journal of Services Marketing, 10(6): 45-61.

Wansink, B. \& Cheney, M. M. (2005) Super Bowls: Serving Bowl Size and Food Consumption, Journal of American Medical Association, 293: 1727-1728.

Wansink, B. \& Van Ittersum, K. (2006) Why Our Eyes Are Bigger than Our Stomach: The Del Bouf Illusion and Food Intake. Dept. of Applied Economics and Management, Cornell University, Ithaca, New York.

Warde, A. \& Martens, L. (2000). Eating out: Social Differentiation, Consumption and Pleasure. New York: Cambridge Press. 
Gastroia: Journal of Gastronomy and Travel Research, Vol. 4, Issue 2, pp.,218-250 , 2020

Investigation of Physical Environment as a Part of Micro Dimension in Restaurants: A Study on Local Consumers

Neslihan ÇETINKAYA, Mehmet Yavuz ÇETINKAYA

Wirtz, J. \& Bateson, J. E. (1999). Consumer Satisfaction With Services: Integrating the Environment Perspective in Services Marketing into the Traditional Disconfirmation Paradigm. Journal of Business Research, 44 (1): 55-66.

Wulf, K. M. (1977) Relationship of Assigned Classroom Seating Area to Achievement Variables, Educational Research Quarterly, 2(2): 56-62.

Yama, M., Ohno, R. \& Soeda, M. (2004) The Influence of environmental Factors on Distance Perception Along Urban Streets, Journal of Architecture and Planning, 580: 79-85.

Yüksekbilgili, Z. (2014). Restoran Seçim Ölçütleri Üzerine Bir Araştırma, Journal of Yasar University, 9 (36): 6353-6360.

Zencir, E. (2017). Restoran Yönetimi, Ed.Meryem Akoğlan Kozak, Ankara: Detay Yayıncilik. 